Piotr Köhler

Instytut Botaniki UJ, Kraków

\title{
KSIĘGOZBIÓR ALEKSANDRA JANA ŚLEŃDZIŃSKIEGO (1848-1881) W ZBIORACH BIBLIOTEKI INSTYTUTU BOTANIKI UNIWERSYTETU JAGIELLOŃSKIEGO
}

Księgozbiór był (szczególnie w XIX w.) jednym z podstawowych elementów naukowego warsztatu botanika. W księgach zapisane były wyniki pracy poprzednich pokoleń, formę ksiąg miały flory oraz klucze do oznaczania roślin i grzybów. Pomimo znacznej liczby księgozbiorów botanicznych, jakie przetrwały do naszych czasów, niewiele z nich doczekało się analizy. Do tych wyjątków należy kolekcja książek botanika i lekarza Franciszka Błońskiego (1867-1910) ${ }^{1}$ opracowana przez Alinę Skirgiełło i Zofię Sidorowicz², biblioteka Franciszka Scheidta (1759-1807), botanika i chemika związanego z Uniwersytetem Jagiellońskim, a następnie z Liceum Krzemienieckim³ ${ }^{3}$ opracowana przez

${ }^{1}$ B. Hryniewiecki: Franciszek Błoński. (Wspomnienie pośmiertne z portretem), „Kosmos” 1911 t. 35 s. 792-799; Mowsz. [J. Mowszowicz]: Błoński Franciszek Ksawery (1867-1910), [w:] S. Feliksiak (red.), Słownik biologów polskich, PWN Warszawa 1987, cyt. s. 77; J. Mowszowicz: Franciszek Błoński (1867-1910), „Wszechświat” 1971 nr 4 (2090) s. 102-103; W. Woj ewo da: Franciszek Błoński (1867-1910) jako mikolog. W sześćdziesiata rocznicę śmierci, „Wiadomości Botaniczne” 1970 t. 14 nr 4 s. 277-279.

${ }^{2}$ A. Skirgiełło, Z. Sidorowicz: Księgozbiór Franciszka Błońskiego „Wiadomości Botaniczne" 1965 t. 9 nr 2 s. 149-153.

${ }^{3}$ M. Bergo nzo ni: Rzecz czytana o Franciszku Scheidt [...], „,Rocznik Towarzystwa Warszawskiego Przyjaciół Nauk" 1816 t. 9 s. 459-470; E. T. [E. Turczyńska]: Scheidt Franciszek (1759-1807), [w:] S. Feliksiak (red.), Słownik biologów polskich, dz. cyt. s. 477; K. T.: Wspomnienie historyczne. Franciszek Scheidt. Professor historyi naturalnej i chemii w Akademii Krakowskiej, „Pielgrzym” 1843 t. 1 s. 313-319; J. Rogowski: O Franciszku Scheidcie i jego książce o elektryczności, „Przegląd Elektrotechniczny” 1966 t. 42 nr 2 s. 79-80; E. Turczyńska: Franciszek Scheidt jako botanik, „Wszechświat” 1973 nr 12 (2122) s. 329-330; Scheidt Franciszek, [w:] G. Ciołek, W. Plapis: Materiały do słownika twórców ogrodów, Warszawa 1968 s. 84. 
Wandę Grębecką ${ }^{4}$, czy też księgozbiór Józefa Jundziłła (1794-1877), profesora Uniwersytetu Wileńskiego i twórcy cennego zielnika 5 , przeanalizowany przez autora niniejszego opracowania ${ }^{6}$. Wymienieni powyżej botanicy w chwili śmierci byli już uznanymi uczonymi. Zmarły w wieku 33 lat Aleksander Jan Śleńdziński był dopiero na progu twórczego naukowego życia. Pomimo tego zebrał interesujący księgozbiór, którego analiza jest przedmiotem niniejszej pracy.

\section{Twórca księgozbioru}

Aleksander Jan Śleńdziński urodził się 7 maja (czyli 25 kwietnia według obowiązującego wtedy w Cesarstwie Rosyjskim kalendarza juliańskiego) 1848 r. w zaścianku Bojaryszki (koło Wiłkomierza), w guberni kowieńskiej. Był synem Aleksandra Józefa Śleńdzińskiego (1803-1878) i Karoliny z domu Korgowd (1812-1883). Ojciec jego był malarzem, studiował malarstwo i rysunek na Uniwersytecie Wileńskim pod kierunkiem Jana Rustema (1762-1835), a u Kazimierza Jelskiego (1782-1867) - rzeźbę. Był także muzykiem, przyjaźnił się ze Stanisławem Moniuszką (1819-1872), a także pisarzem Józefem Ignacym Kraszewskim (1812-1887). Aleksander Jan, późniejszy twórca omawianego księgozbioru, początkowe nauki pobierał prawdopodobnie w Wilnie. W latach sześćdziesiątych XIX w. lekcji przyrody udzielał mu wspomniany Józef Jundziłł, którego był jednym z najpóźniejszych, ale i najznakomitszych uczniów.

Jeden ze starszych braci twórcy omawianego księgozbioru, malarz Wincenty Leopold (1837-1909), przebywał w latach 1867-1872 w Charkowie. Pomagał wtedy swym braciom w studiach. Dzięki jego pomocy Aleksander Jan Śleńdziński studiował na Uniwersytecie w Charkowie przez dwa semestry w roku akademickim

\footnotetext{
${ }^{4}$ W. Gręb ecka: Księgozbiór Franciszka Scheidta (1759-1807), „Kwartalnik Historii Nauki i Techniki" 2003 t. 48 nr 3-4 s. 79-93.

${ }^{5}$ A. F. Ad amowicz: Józef Jundziłt, prof. b. Uniwersytetu Wileńskiego , „Kłosy” 1877 t. XXIV nr 624 (Warszawa, 2 (14) VI 1877) s. 373 [portret], 375-376, 401-402; Dr J. B. [J. Bieliński]: Jundziłł Józef [...], [w:] Wielka Encyklopedya Powszechna Ilustrowana, Warszawa 1903 t. XXXIII s. 168-170; J. Gintowt: Józef Jundziłł, „Wiadomości Farmaceutyczne” 1877 t. IV s. 128; P. Köhler: Józef Jundziłł (1794-1877). Materiały do biografii, „Kwartalnik Historii Nauki i Techniki” 2004 t. 49 nr 1 s. 83-117; P. Köhler: Badania Józefa Jundziłła nad florq Litwy po 1830 r. (w świetle nieznanych materiałów rękopiśmiennych), „Kwartalnik Historii Nauki i Techniki" 1997 t. 42 nr 1 s. 43-74; P. Köhle r: Collections of 18th Century Vilna Botanists in the JózefJundziłł Herbarium , „Botanical Journal of Scotland” 1994 t. 46 nr 4 s. 589-593; P. Kö hl er: Leksykon Botaników Polskich. 26. Józef Jundziłł, „Wiadomości Botaniczne” 1998 t. 42 nr 2 s. 87-89; P. Kö hl er: Portrety Botaników Polskich. Portraits of Polish Botanists. Józef Jundziłt, „Wiadomości Botaniczne” 1995 t. 39 nr 3/4 s. 77; P. Köhler: Portrety Botaników Polskich. Portraits of Polish Botanists. Józef Jundziłt, „Wiadomości Botaniczne” 1995 t. 39 nr 3/4 s. 78; P. Kö hle r: Rośliny z terenu Białorusi w zielniku Józefa Jundziłła, „Kwartalnik Historii Nauki i Techniki" 1994 t. 39 nr 3-4 s. 93-102; Mowsz. [J. Mowszowicz]: Jundziłł Józef (17941877), [w:] S. Feliksiak (red.): Słownik biologów polskich, dz. cyt. s. 239-240.

${ }^{6}$ P. Kö hler: Biblioteka naukowa Józefa Jundziłła (1794-1877), „Kwartalnik Historii Nauki i Techniki" 1997 t. 42 nr 3-4 s. 63-84.
} 
1869/1870. Na dalsze studia przeniósł się do Krakowa, gdzie w latach 1871-1875 studiował na Wydziale Filozoficznym Uniwersytetu Jagiellońskiego. Jeszcze podczas ostatniego roku studiów Aleksander Jan Śleńdziński został 1 października $1874 \mathrm{r}$. asystentem w Katedrze Botaniki i Ogrodzie Botanicznym na Wydziale Filozoficznym UJ u prof. Ignacego Rafała Czerwiakowskiego (1808-1882). Po czterech latach musiał jednak opuścić asystenturę.

Już podczas studiów nawiązał współpracę z Komisją Fizjograficzną Akademii Umiejętności, która w latach 1873-1880 finansowała jego badania florystyczne: w 1873 r. - w obwodach brzeżańskim, czortkowskim, lwowskim, stanisławowskim, tarnopolskim i złoczowskim, w latach 1874-1875 - w okolicach Kołomyi, w latach 1876-1879 - na Podolu, a w 1880 r. - na Pokuciu. W 1877 r. jego współpraca z Komisją Fizjograficzną AU została sformalizowana: w dniu 26 kwietnia tego roku został mianowany jej współpracownikiem. W 1881 r. Komisja Fizjograficzna AU sfinansowała Śleńdzińskiemu opracowanie jego materiałów florystycznych zebranych rok wcześniej

Aleksander Jan Śleńdziński był bardzo wprawnym botanikiem-florystą. Podczas badań terenowych zebrał znaczny zielnik. Obecnie jego zbiory znajdują się w Zielniku Instytutu Botaniki PAN w Krakowie (KRAM) oraz w Zielniku Instytutu Botaniki Uniwersytetu Jagiellońskiego (KRA). Rezultatem prowadzonych przez Śleńdzińskiego badań, oprócz zielników, były publikacje. Zdążył opublikować jedynie 7 prac związanych z roślinami naczyniowymi ${ }^{8}$ oraz 1 pracę teoretyczną dotyczącą zbiorów przyrodniczych ${ }^{9}$.

7 P. Köhler: Botanika w Towarzystwie Naukowym Krakowskim, Akademii Umiejętności i Polskiej Akademii Umiejętności. Botany at the Academic Society of Cracow, Academy of Sciences and Letters and the Polish Academy of Sciences and Letters (1815-1952), Ser:: „Studia i materiały do dziejów Polskiej Akademii Umiejętności” t. 2 Kraków 2002, cyt. s. 343.

${ }^{8}$ Układ chronologiczny publikacji. Śl eń dziński A. J.: Przyczynek do flory obwodów brzeżańskiego i tarnopolskiego, oraz i części przyległych im obwodów - lwowskiego, złoczowskiego, czortkowskiego i stanisławowskiego, „Sprawozdanie Komisyi fizyjograficznej” [za 1873] 1874 t. 8 s. (49)-(70); Śleńdzińs ki A. J.: Przyczynek do flory obwodu kołomyjskiego, „Sprawozdanie Komisyi fizyjograficznej" [za 1874] 1875 t. 9 s. (49)-(71); Śleńdziński A. J.: Wykaz roślin zebranych w obwodzie kołomyjskim w roku 1875, „Sprawozdanie Komisyi fizyjograficznej" [za 1875] 1876 t. 10: (91)-(112); Śl eńd ziński A. J.: Rośliny z okolicy Podola pomiędzy dolnym Zbruczem, Dniestrem a dolnym Seretem, „Sprawozdanie Komisyi fizyjograficznej” [za 1876] 1877 t. 11 s. (155)-(197); Śleńdziński A. J.: Rośliny międzyrzecza Zbruczu i Seretu, „Sprawozdanie Komisyi fizyjograficznej” [za 1877] 1878 t. 12 s. (68)-(107); Śleńdziński A. J.: Rośliny międzyrzecza Zbruczu i Seretu, przeważnie górnego ich biegu, zebrane w roku 1878, „Sprawozdanie Komisyi fizyjograficznej” [za 1878] 1879 t. 13 s. (183)-(220); Śleńdziński A. J.: Rośliny dolnego międzyrzecza Seretu i Złotej Lipy, oraz kilku miejscowości temu międzyrzeczu przyległych z wycieczki w roku 1879 odbytej, „Sprawozdanie Komisyi fizyjograficznej” [za 1880] 1881 t. 15 s. (91)-(156).

${ }^{9}$ A. J. Śleńd zińs ki: Poradnik dla urządzających zbiory przyrodnicze. Sposoby wypychania ssaków, ptaków, płazów, gadów i ryb, zbieranie i zachowanie owadów, pajęczaków, robaków $i$ innych niższych zwierząt, zbieranie i zasuszanie roślin, oraz przysposabianie minerałów do zbiorów [...], Nakł. i druk. W. Korneckiego, Kraków 187499 s. 
Zmarł $3^{10}$ lub $4^{11}$ maja 1881 r. w Krakowie w jednej z klinik Uniwersytetu Jagiellońskiego (przy obecnej ul. Kopernika 15) na wysiękowe zapalenie opłucnej. Pogrzeb odbył się 5 maja 1881 r. na Cmentarzu Rakowickim w Krakowie ${ }^{12}$.

\section{Przypuszczalna historia księgozbioru}

Jedynie w ogólnych zarysach można odtworzyć historię kolekcji. Podstawą są dokonywane przez Śleńdzińskiego adnotacje w książkach wchodzących w skład tego zbioru. Początki przyrodniczych zainteresowań autora księgozbioru sięgają lat sześćdziesiątych XIX w., o czym świadczą lekcje pobierane u botanika J. Jundziłła. Być może w ślad za krystalizacją zainteresowań pojawiła się u Śleńdzińskiego potrzeba posiadania własnego księgozbioru. Z tamtego okresu brak jednak autorskich wpisów w książkach. Najwcześniejszy wpis, o treści: Ex libris A.J. Śleńdziński, emit Charkoviae 3.(15) Julii 186913, pochodzi z 15 lipca 1869 r. Dzień później zakupił następną książkę, co odnotował w niej następująco: z ksiąg A. J. Śleńdzińskiego, nabyto w Charkowie 1869 r. Lipca 4(16) $d \cdot{ }^{14}$ (ryc. 1). Jak widać, obie książki zostały zakupione jeszcze podczas studiów w Charkowie. Natomiast ostatni odnotowany zakup miał miejsce już w Krakowie w dniu 1 lutego 1875 r., na co wskazuje odręczny wpis: Kraków 1/II 75 A. J. Śleńdzińskiego ${ }^{15}$. Łącznie na wszystkich książkach jest siedem własnoręcznych wpisów autora księgozbioru.

Po śmierci Aleksandra Jana Śleńdzińskiego księgozbiór zostałzakupiony w 1883 r. za 15 i pół florena do biblioteki Ogrodu Botanicznego i Katedry Botaniki UJ ${ }^{16}$.

${ }^{10}$ Według publikowanych nekrologów.

${ }^{11}$ Archiwum Narodowe w Krakowie, Oddział II, sygn. U.Z. 40: „Spis zmarłych chrześcijan miejscowych i obcych na rok 1881" 1. 769.

${ }^{12}$ [a n on im ]: Aleksander Śleńdziński [...]. „Czas” nr 108 (12 V 1881), s. 2; [a n o ni m] : Aleksander Śleńdziński, „Gazeta Krakowska” nr 12 (8 V 1881), s. 3-4; [anonim]: Ślendziński Aleksander [...], ,"Tygodnik Illustrowany" 1882, t. 13, s. 398; K. R. H r y s z k o : Drzewo genealogiczne rodziny Sleńdzińskich, „Ananke” 2007 nr 1(49) s. 8-17; R. Ja n o n i e n è : Sleńdziński (Slędziński, Slendziński, Śledziński) Aleksander Józef (1803-1878), malarz, [w:] Polski Słownik Biograficzny 1997-1998 t. XXXVIII s. 555; P. Kö h l e r : Śleńdziński (Ślendziński, Sleńdziński) Aleksander Jan (1848-1881), botanik florysta, [w:] Polski Słownik Biograficzny 2015 t. 50 s. 544-545; P. Kö hle r: Zlokalizowanie grobu Aleksandra Jana Śleńdzińskiego (1848-1881) na Cmentarzu Rakowickim w Krakowie, „Wiadomości Botaniczne” 61, https://doi.org/10.5586/ wb.2017.019; I. S z y [s z ył o w i c z]: Aleksander Ślendziński, „Przegląd Akademicki” 1881 t. 1 s. 279-280; A. Z e m a n e k: Aleksander Józef Ślendziński (1849-1881) w 140-rocznicę urodzin, „Wiadomości Botaniczne” 1989 t. 33 nr 4 s. 135-138; Ta ż: Aleksander Ślendziński (18491881), „Wiadomości Botaniczne” 1991 t. 35 nr 1 s. 47; Ta ż : Leksykon Botaników Polskich. 2. Aleksander Józef Ślendziński (Śleńdziński), „Wiadomości Botaniczne” 1991 t. 35 nr 1 s. 70.

${ }^{13} \mathrm{Nr}$ inw. 70. K. Linne: Systema vegetabilium, Gottingae 1797; sygn.: Starodruki.

${ }^{14} \mathrm{Nr}$ inw. 63. J. Loiseleur-Deslong cham ps: Considérations sur les céréales et principalement sur les froments, Paris 1842; sygn.: Starodruki.

${ }^{15} \mathrm{Nr}$ inw. 78. M. Szubert Spis roślin ogrodu botanicznego warszawskiego, Warszawa 1824; sygn.: Polonica.

${ }^{16}$ Biblioteka Instytutu Botaniki UJ: Inwentarz Ogrodu Botanicznego c.k. Uniwersytetu Jagiellońskiego w Krakowie [około 1878-1933], poz. od 55 do 82. 


\section{Wielkość zbioru}

Książki składające się na księgozbiór po zakupie w 1883 r. zostały wpisane do inwentarza Ogrodu Botanicznego i Katedry Botaniki UJ od pozycji 55 do 82 alfabetycznie według autorów ${ }^{17}$. Tak więc zbiór liczył wtedy 28 pozycji inwentarzowych. Jednakże nr 59 zawierał dwa egzemplarze książki Ferdinanda Cohna Kryptogamen flora von Schlesien, a nr 81 - dwa egzemplarze Flora der Stadt Lemberg Aleksandra Zawadzkiego.

\section{Liczebność poszczególnych działów}

Księgozbiór jest nadzwyczaj jednorodny. Zawiera jeden starodruk. Pozostałe prace opublikowane zostały w XIX w. Druków polskich jest 10 (prawie 36\%). Druki obce stanowią zdecydowaną większość (ponad 64\%) księgozbioru.

Tabela 1. Liczebność działów księgozbioru A. J. Śleńdzińskiego

\begin{tabular}{|l|c|c|c|}
\hline \multicolumn{1}{|c|}{ Dział } & $\begin{array}{c}\text { Druki polskie } \\
\text { (lub dotyczące } \\
\text { flory ziem polskich) }\end{array}$ & Druki obce & Razem \\
\hline Druki do końca XVIII w. & 0 & 1 & 1 \\
\hline Druki 1801-1876 & 10 & 17 & 27 \\
\hline Razem: & 10 & 18 & 28 \\
\hline
\end{tabular}

\section{Struktura tematyczna}

Struktura tematyczna księgozbioru jest bardzo jednolita: dotyczy on botaniki (w ujęciu dziewiętnastowiecznym, czyli obejmującej zarówno rośliny, jak i grzyby).

Tabela 2. Charakterystyka tematyki książek ze zbioru A. J. Śleńdzińskiego

\begin{tabular}{|l|c|c|c|}
\hline Treść dzieł & Druki polskie & Druki zagraniczne & Razem \\
\hline taksonomia roślin & 0 & 2 & 2 \\
\hline $\begin{array}{l}\text { botanika teoretyczna, } \\
\text { słowniki botaniczne }\end{array}$ & 1 & 2 & 3 \\
\hline $\begin{array}{l}\text { spisy roślin ogrodów } \\
\text { botanicznych }\end{array}$ & 1 & 0 & 1 \\
\hline mykologia & 0 & 3 & 3 \\
\hline rośliny skrytopłciowe & 0 & 1 & 1 \\
\hline flory & 8 & 1 & 16 \\
\hline briologia & 0 & 1 & 1 \\
\hline botanika użytkowa & 0 & 8 & 1 \\
\hline
\end{tabular}

${ }^{17}$ Biblioteka Instytutu Botaniki UJ: Inwentarz Ogrodu Botanicznego c.k. Uniwersytetu Jagiellońskiego w Krakowie [około 1878-1933]. 
Flory. Większość wśród książek w bibliotece A. J. Śleńdzińskiego można zaklasyfikować jako flory, czyli publikacje zawierające zestawienia gatunków roślin rosnących na określonych obszarach. Flory zagraniczne dotyczyły głównie Austrii, Chorwacji, Niemiec (w tym Śląska), Slawonii i Węgier, a więc rejonów bliskich botanicznie z punktu widzenia badacza pracującego w Krakowie czy Galicji. Natomiast flory „polskie” dotyczyły takich obszarów, jak Ukraina, Litwa, Królestwo Polskie i Galicja. Książki te wydane zostały między 1830 a 1869 rokiem. Uwagę zwraca brak niektórych podstawowych pozycji dla badacza roślin Galicji, jak Primitiae florae Galiciae [... ${ }^{18}$ Willibalda Bessera (1784-1842); brak też innych publikacji tego botanika. Brak Flora Carpatorum [...] ${ }^{19}$ Szweda Görana Wahlenberga (1780-1851) ${ }^{20}$, a także Przeglądu flory okolic Krakowa ${ }^{21}$ Feliksa Berdaua (1826-1895). Być może Śleńdziński mógł korzystać z egzemplarzy dostępnych w bibliotekach, dzięki czemu nie musiał ich nabywać na własność.

Botanika teoretyczna. Do tego działu zaliczone zostały trzy książki. Philosophiae botanicae (wydanie z 1809 r.) Karola Linneusza jest rodzajem zbioru zasad, którymi należy się kierować w taksonomii roślin. Słownik wyrazów botanicznych (1830) Aleksandra Pławskiego zawiera objaśnienia fachowych terminów łacińskich, uzupełniony jest skorowidzem polsko-niemiecko-francusko-łacińskim. Natomiast Schmidlins Anleitung zum Botanisieren und zur Anlegung von Pflanzensammlungen (1846) Ottona Wünschego jest rodzajem poradnika na temat zbierania roślin i tworzenia zbiorów botanicznych. Tytuł ten wskazuje na dodatkowe zainteresowania Śleńdzińskiego, jakimi były zbiory przyrodnicze

${ }^{18}$ W. S. J. G. Bess er: Primitiae florae Galiciae Austriacae utriusque. Encheiridion ad excursiones botanicas concinnatium, Vienna 1809, t. 1. ss. XVIII + 399, t. 2. ss. VIII + 423.

${ }^{19} \mathrm{G}$. Wahlen berg: Flora carpatorum principalium exhibens plantas in montibus carpaticis inter flumina Waagum et Dunajetz eorumque ramos Arvam et Popradum crescentes [...], Göttingae 1814 ss. CXVIII + 408.

${ }^{20}$ Göran Wahlenberg był szwedzkim doktorem medycyny i przyrodnikiem. Po ukończeniu uniwersytetu w Uppsali był tam zatrudniony, a w 1829 r. został profesorem medycyny i botaniki. Więcej na ten temat patrz: L. Frey: Szwedzki botanik w Tatrach, „Wiadomości Botaniczne" 2001 t. 45 nr 3/4 s. 119-122.

${ }^{21}$ F. Berdau: Przegląd flory okolic Krakowa, „Rocznik Towarzystwa Naukowego Krakowskiego" 1859 t. 26 s. 213-658. Wydano również separatum z tytułem polskim na okładce: Flora okolic Krakowa czyli wyliczenie roślin $w W$ [ielkiem] Ks[ięstwie] Krakowskiem oraz w przyległych częściach obwodów wadowickiego i bocheńskiego, jako też w Dolinie Ojcowskiej dziko rosnacych, a z tytułem łacińskim na stronie tytułowej: Flora cracoviensis sive enumeratio plantarum in Magno Ducatu Cracoviensi et adjacentibus regionibus provinciae vadovicensis et bochnensis, tum in valle quae dicitur Ojców sponte crescentium, ss. VIII +448 . W literaturze praca ta cytowana jest pod jednym z trzech powyższych tytułów. Porównaj: P. Köhler: Bibliografia botaniki w Towarzystwie Naukowym Krakowskim, Akademii Umiejętności i Polskiej Akademii Umiejętności (1818-1952-2000). Bibliography of botany at the Academic Society of Cracow, Academy of Sciences and Letters and the Polish Academy of Sciences and Letters (18181952-2000), Kraków 2004, cyt. s. 25. 
i ich tworzenie. 0 tych zainteresowaniach świadczy także pierwsza publikacja Śleńdzińskiego - Poradnik dla urządzajacych zbiory przyrodnicze $e^{22}$ - zawierająca opisy metod wypychania i innej preparatyki ssaków, ptaków, płazów, gadów i ryb, zbierania i przechowywania różnych typów bezkręgowców, zbierania i suszenia roślin i grzybów oraz przygotowywania okazów geologicznych; opracowanie to zawiera także rady dotyczące kompozycji różnych typów przyrodniczych ekspozycji muzealnych. Jest to niemal wierny przekład pracy Karla Glasla Ueber das Anlegen von Naturaliensammlungen als Hilfsmittel bei dem Unterrichte in der Naturgeschichte in der Realschule ${ }^{23}$.

Mykologia. Dział ten obejmuje trzy książki: Françoisa Simona Cordiera Guide de l'amateur de champignons, ou précis de l'histoire des champignons alimentaires, vénéneux, et employés dans les arts, qui croissent sur le sol de la France (1826), Johanna Georga Billa Najważniejsze grzyby jadalne i jadowite. Wyjaśnienie do tablic ściennych szkolnych; wykonanych według natury w barwnych odciskach przez Antoniego Hartingera [...] (1860) oraz Karla W. G. L. Fuckela Symbolae mycologicae. Beiträge zur Kenntniss der Rheinischen Pilze (1869-1870). Tytuły te świadczą o amatorskim zainteresowaniu grzybami A. J. Śleńdzińskiego.

Inne działy botaniki reprezentowane są przez pojedyncze tytuły.

\section{Struktura językowa}

Łacina, która była językiem nauki jeszcze w XVIII w., w czasach Śleńdzińskiego ustępowała nowożytnym językom narodowym. Widać to na przykładzie księgozbioru tego botanika. Połowa dzieł (14) została wydana w języku niemieckim, a po łacinie - 7 tytułów, w tym kilka dotyczących ziem polskich autorstwa Franciszka Herbicha $^{24}$ czy Stanisława Dembosza ${ }^{25}$ (ryc. 2). W języku polskim wydano pięć tytułów, jak np. Michała Szuberta Spis roślin ogrodu botanicznego warszawskiego (ryc. 3) czy wspomniana praca A. Pławskiego. Najmniej tytułów - 2 - wydano po francusku. Tak mała liczba francuskich książek była wynikiem odległości geograficznej od terenów głównego zainteresowania florystycznego Śleńdzińskiego ${ }^{26}$.

${ }^{22}$ A. J. Śleńdziński: Poradnik dla urządzających zbiory przyrodnicze, Kraków 1874.

${ }^{23}$ K. Glasl: Ueber das Anlegen von Naturaliensammlungen als Hilfsmittel bei dem Unterrichte in der Naturgeschichte in der Realschule. [w:] Jahres-Bericht der k. $k$. Ober-Realschule am Schottenfelde in Wien für das Studienjahr 1854-55, Wien 1855 s. 23-41.

${ }^{24}$ Np. F. Herbich: Additamentum ad floram Galiciae, Przemyśl 1831.

${ }^{25}$ S. Dembosz: Tentamen florae territorii cracoviensis medicae sive Enumeratio Plantarum Medicinalium circa Cracoviam sponte nascentium ac exoticarum secundum systema Linnei disposita, Cracoviae [1841].

${ }^{26}$ Może też wyższą ceną publikacji francuskich? 


\section{Struktura chronologiczna}

Na strukturę chronologiczną księgozbioru Śleńdzińskiego wpływ miał głównie jeden czynnik: rozwój w tej części Europy dziedziny nauki, którą uprawiał autor biblioteki. Najstarsza książka z omawianego księgozbioru została wydana w 1797 r.; jest to K. Linneusza Systema vegetabilium. Najmłodsze książki, jakie znalazły się w posiadaniu A. J. Śleńdzińskiego, a które zostały nabyte do zbiorów UJ, pochodzą z 1876 r. - są to C. Aberlego Die Gefässpflanzen des Lk. botanischen Gartens in Salzburg. I. Allgemeiner Theil enthaltend eine vergleichende Zusammenstellung der gebrauchlicheren Pflanzensysteme und eine statistische Uebersicht der Artenzahl und Verbreitung der Ordnungen (Familien) der lebenden und fossilen Gefasspflanzen... oraz F. Cohna Kryptogamen flora von Schlesien (nr inw. 59). W ciągu osiemdziesięciu lat, jakie upłynęły między opublikowaniem najstarszej i najmłodszej książki z omawianego księgozbioru, nastąpił szybki rozwój florystyki. Większość książek opublikowana została w drugiej połowie tego osiemdziesięciolecia (ryc. 4). Jak widać, Śleńdziński starał się posługiwać najnowszą dostępną mu literaturą, dzięki czemu szybko osiągnął profesjonalny poziom uprawiania florystyki, co zostało dostrzeżone przez Komisję Fizjograficzną AU, która mianowała go współpracownikiem.

\section{Struktura geografii wydawniczej}

Analiza struktury geografii wydawniczej księgozbioru przyrodniczego umożliwia wskazanie powiązań między ówczesnymi centrami rozwoju danej dyscypliny nauki a twórcą kolekcji.

Najwięcej książek wydanych zostało w Niemczech - 10 tytułów - w 7 miastach, w tym w Berlinie, Getyndze i Wrocławiu - po dwa tytuły. Nieco mniej - 9 tytułów - wydano w Polsce (na ziemiach polskich): w Warszawie - 3, w Wilnie - 2, a w Krakowie, Lwowie, Przemyślu i Stanisławowie - po 1 tytule. W Austrii wydano 7 tytułów, wszystkie w Wiedniu. We Francji 2 tytuły, oba w Paryżu. Taki rozkład struktury geografii wydawniczej wskazuje, że Śleńdziński był pod wpływem niemieckich ośrodków botanicznych.

Nie należy dziwić się tak znacznemu udziałowi książek wydanych w Niemczech. W owym czasie botanika niemiecka była wiodącą w Europie. Niemieckie ośrodki botaniczne miały największą i być może najtańszą produkcję wydawniczą w dziedzinie, która interesowała Śleńdzińskiego. Co więcej, podobieństwo florystyczne terenów Niemiec i ziem polskich, szczególnie terenów nizinnych, jest znaczne. Wszystkie te czynniki wpływały dodatnio na posługiwanie się niemieckimi opracowaniami botanicznymi. Podobnie zrozumiały jest także wysoki udział wydawców z ziem polskich. Głównym geograficznym obszarem zainteresowań Śleńdzińskiego były właśnie te obszary. Flory tych ziem czy to jako całości, czy to tylko mniejszych części, dotyczyły polskie opracowania. 


\section{Oprawy, marginalia, dedykacje}

Z zapisów w najstarszej księdze inwentarzowej Biblioteki Instytutu Botaniki UJ wynika, że większość książek Śleńdzińskiego po zakupie została oprawiona lub też ich oprawy uzupełniono. Obecnie oprawy te miałyby więc około 150 lat. Na grzbietach 12 książek jest wytłoczony złotem znak imienny introligatora przedstawiający litery B i K (ostatnia odwrócona o $180^{\circ}$ ) połączone owalem (ryc. 5). Dr Michał Myśliński z Instytutu Sztuki PAN w Krakowie zidentyfikował ten monogram jako znak znanego krakowskiego introligatora Karola Blechy (1836-1888) ${ }^{27}$. Najstarsza książka oznaczona tym znakiem pochodzi z 1797 r. (K. Linneusz, Systema vegetabilium), najmłodsza zaś (C. Aberle, Vergleichende Zusammenstellung der gebräuchlicheren Pflanzensysteme und statistische Uebersicht) została wydana dopiero w 1876 r. Nie wiadomo, czy zostały oznaczone jeszcze przez A. J. Śleńdzińskiego, czy już po jego śmierci i nabyciu księgozbioru do biblioteki Ogrodu Botanicznego UJ.

Wpisy własnościowe A. J. Śleńdzińskiego znajdują się na 6 publikacjach. Cztery z tych wpisów są datowane. Dwa z nich wskazują na nabycie książek jeszcze podczas pobytu w Charkowie: Ex libris A.J. Śleńdziński, emit Charkoviae 3.(15) Julii 1869 (K. Linneusz, Systema vegetabilium) oraz z ksiag A. J. Śleńdzińskiego, nabyto w Charkowie 1869 r. Lipca 4(16) d. (J. Loiseleur-Deslongchamps, Considérations sur les céréales et principalement sur les froments) (ryc. 1). Dwa dalsze wskazują na nabycie książek już w Krakowie: 12/2 [18]74 A.J. Śleńdzińskiego (S. Dembosz, Tentamen florae territorii cracoviensis medicae) (ryc. 2) oraz Kraków 1/II [18]75 A. J. Śleńdzińskiego (M. Szubert, Spis roślin ogrodu botanicznego warszawskiego) (ryc. 3). Kolejne dwa są niedatowane i zawierają jedynie frazę: A.J. Śleńdzińskiego (F. S. Cordier, Guide de l'amateur de champignons, ou précis de l'histoire des champignons alimentaires, vénéneux, et employés dans les arts, qui croissent sur le sol de la France oraz J. Waga, Flora polonica phanerogama sive descriptiones plantarum phanerogamicarum [...]).

Na trzech książkach widnieją pieczątki własnościowe Ignacego Rafała Czerwiakowskiego (J. Jundziłł, Opisanie roślin w Litwie..., A. Zawadzki, Enumeratio plantarum Galiciae Bukovinae i E. Schmidlin, Anleitung zum Botanisiren und zur Anlegung der Pflanzensammlungen). I. R. Czerwiakowski był profesorem botaniki i kierownikiem Ogrodu Botanicznego UJ, mentorem Śleńdzińskiego. Pieczątki te wskazują, że te trzy książki były wcześniej własnością profesora, u którego studiował A. J. Śleńdziński. Być może gdy I. R. Czerwiakowski przeszedł na emeryturę w 1878 r., podarował je jednemu z najzdolniejszych swych asystentów.

${ }^{27}$ Informacje pisemne otrzymane od dra Michała Myślińskiego w dn. 18 II, 27 II, 9 III i 10 III $2015 \mathrm{r}$. 


\section{Funkcja księgozbioru}

Analiza zachowanego księgozbioru pozwala na wysunięcie wniosku dotyczącego jego funkcji. Był przede wszystkim częścią warsztatu pracy botanika-florysty. Stanowił źródło wiedzy o florze ziem polskich oraz ościennych części Europy Środkowej. Dostarczał niezbędnych wzorców do opisów gatunków, które zamieszczane były ówcześnie w pracach florystycznych. Analizując ten księgozbiór, można stwierdzić ścisły związek doboru dzieł z zainteresowaniami naukowymi jego właściciela: była to głównie botanika roślin kwiatowych. Struktura chronologiczna księgozbioru wskazuje na szybki rozwój botaniki w okresie naukowej aktywności jego właściciela. Mała liczebność biblioteki może wynikać z jednej strony z niewielkich możliwości finansowych jej właściciela i krótkiego okresu gromadzenia zbioru, a z drugiej - z prawdopodobnego dostępu Śleńdzińskiego do niektórych podstawowych dzieł dotyczących flory polskiej, na co wskazuje brak tych dzieł w księgozbiorze. Omówiona biblioteka prezentuje formę będącą rezultatem dziewiętnastowiecznej specjalizacji w obrębie poszczególnych dziedzin wiedzy. Analiza księgozbioru Aleksandra J. Śleńdzińskiego rzuca także dodatkowe światło na tego zapomnianego uczonego.

\section{ANEKS}

Spis książek tworzących księgozbiór A. J. Śleńdzińskiego w zbiorach Biblioteki Instytutu Botaniki UJ; podano numer inwentarzowy oraz sygnaturę. Symbolem BO>| oznaczono książki zawierające na grzbietach znak imienny introligatora Karola Blechy.

Nr inw. 55, sygn.: II 3567

Carl Aberle: Vergleichende Zusammenstellung der gebräuchlicheren Pflanzensysteme und statistische Uebersicht der Artenzahl und Verbreitung der Ordnungen (Familien) der lebenden und fossilen Gefässpflanzen. Wien 1876, Verlag von Friedrich Beck, ss. $\mathrm{IV}+133$.

Oprawa bordowa z poł. XIX w.; BO>I

Nr inw. 56, egzemplarz zaginiony

Antoni Andrzejowski: Flora Ukrainy czyli opis roślin dzikich. Warszawa 1869, w drukarni Gazety Polskiej, ss. XVI+93.

Nr inw. 57, sygn.: I 483

Paul Friedrich August Ascherson, W. Lackowitz: Dr. Paul Ascherson's Flora der Provinz Brandenburg, der Altmark und des Herzogthums Magdeburg. Im Auszuge 
bearbeitet unter Mitwirkung des Verfassers von W. Lackowitz. Berlin 1866, Verlag von August Hirschwald, ss. X+518. BO>1

Nr inw. 58, sygn.: Polonica 18

Jan Jerzy Bill: Najważniejsze grzyby jadalne i jadowite. Wyjaśnienie ściennych tablic szkolnych, wykonanych według natury $w$ barwnych odciskach przez Antoniego Hartingera; wydanych pod tymże samym tytułem przez M. A. Beckera. Wiedeń 1860, c.k. skład książek szkolnych, ss. VI+145.

Nr inw. 59, sygn.: II 4691

Ferdinand Cohn: Kryptogamen-Flora von Schlesien. In Namen der Schlesischen Gesellschaft für vaterländische Kultur herausgegeben von ... Erster Band. Breslau 1876, J. U. Kern's Verlag, ss. XII+471.

Na s. tytułowej, przedtytułowej oraz na s. 27 podpis Mariana Raciborskiego (1863-1917); oprawa ok. z I poł. XX w.; liczne wpisy ołówkiem - głównie polskie ekwiwalenty niemieckich nazw miejscowości, oraz inne notatki prawdopodobnie M. Raciborskiego, np. na s. 339 przy gatunku Preissia commutata notatka: 30 Maj [18]87 oznaczył M. Rac.[iborski]

Nr inw. 60, sygn.: I 105

François Simon Cordier: Guide de l'amateur de champignons, ou précis de l'histoire des champignons alimentaires, vénéneux, et employés dans les arts, qui croissent sur le sol de la France. Paris 1826, Galerie de Bossange Père, ss. X+248.

Oprawa bordowa z poł. XIX w.; notatka na s. tytułowej: A.J. Śleńdzińskiego; BO>|

Nr inw. 61, sygn.: Starodruki - egzemplarz nieodszukany

P. F. Cüsie: Anleitung die Pflanzen zu [Anleitung die im mittleren und nördlichen Deutschland wildwachsenden Pflanzen auf eine leichte und sichere Weise durch eigene Untersuchung zu bestimmen. Von P. F. Curie. Fünfte verbesserte Auflage. Kittlitz in der Oberlausitz 1843.

Nr inw. 62, sygn.: II 3447

Stanisław Dembosz: Tentamen florae territorii cracoviensis medicae. Cracoviae [1841], ss. 226.

Oprawa z połowy XIX w.; na okładce podpis: 12/2 [18]74 A.J. Śleńdzińskiego, na s. 6 nlb. podpis: E[ugeniusz] Janota M.[?] I. [?] 1857.

Nr inw. 63, sygn.: Starodruki

[Jean] M. Loiseleur-Deslongchamps: Considérations surles céréales, et principalement 
sur les froments. (partie historique). Paris 1842, Libraire de Madame V ${ }^{\mathrm{e}}$ BouchardHuzard, ss. (1)-(180).

Współoprawne: Considérations sur les céréales, et principalement sur les froments. (partie pratique et expérimentale). Paris 1843, Libraire de Madame Ve BouchardHuzard, ss. (1)-(248).

Uwaga w starym inwentarzu: „stara oprawa wyb. uw... [nieczytelne]”; grzbiet skórzany, okładki z poł. XIX w.; na s. przedtytułowej wpis Śleńdzińskiego: z ksiąg A. J. Śleńdzińskiego, nabyto w Charkowie 1869 r. Lipca 4(16) d., na s. 3 okładki wpis w języku rosyjskim, prawdopodobnie tłumaczenie tytułu; $\mathrm{BO}>1$

Nr inw. 64, sygn.: I 547

A. B. Frank: Pflanzen-Tabellen zur leichten, schnellen und sichern Bestimmung der höheren Gewächse Nord- und Mittel-Deutschlands, nebst zwei besondern Tabellen zur Bestimmung der deutschen Holzgewächse nach dem Laube, sowie im blattlosen winterlichen Zustande. Leipzig 1874, Verlag von Heinrich Schmidt, ss. XXVIII+176. oprawa oryginalna, $\mathrm{BO}>1$

Nr inw. 65, sygn.: II 871

Leopold Fuckel, 1871-1872: Symbolae mycologicae. Beiträge zur Kenntniss der rheinischen Pilze. Jahrbücher des Nassauischen Vereins für Naturkunde XXV und XXVI: 287-346.

Jest to część rocznika 25/26 od strony 287 do 495 zawierająca, oprócz powyższego, także następujące opracowania:

R. Fresenius: Analyse der Victoria-Quelle in Bad Ems. Jahrbücher des Nassauischen Vereins für Naturkunde XXV und XXVI: 347-360.

R. Fresenius: Analyse der Römer-Quelle in Bad Ems. Jahrbücher des Nassauischen Vereins für Naturkunde XXV und XXVI: 361-380.

C. Neubauer: Chemische Untersuchungen über das Reifen der Trauben, ausgeführt in der agricultur-chemischen Versuchs-Station zu Wiesbaden. Jahrbücher des Nassauischen Vereins für Naturkunde XXV und XXVI: 381-411.

C. Neubauer: Most- und Treber-Analysen aus dem Jahre 1868. Jahrbücher des Nassauischen Vereins für Naturkunde XXV und XXVI: 412-419.

L. Fuckel: Ein mycologischer Beobachtungsgarten. Jahrbücher des Nassauischen Vereins für Naturkunde XXV und XXVI: 420-423.

A. Rössler: Beobachtungen über einige in Gärten vorkommende Kleinschmetterlinge. Jahrbücher des Nassauischen Vereins für Naturkunde XXV und XXVI: 424-426.

A. Rössler: Zur naturgeschichte von Agrostis Tritici Lihn. = fumosa L. und obelisca 
S. V. . Jahrbücher des Nassauischen Vereins für Naturkunde XXV und XXVI: 427-432.

A. Fuchs: Beobachtungen über einige Lepidopteren. Jahrbücher des Nassauischen Vereins für Naturkunde XXV und XXVI: 433-438.

C. L. Kirschbaum: Zoologische Mittheilungen. Jahrbücher des Nassauischen Vereins für Naturkunde XXV und XXVI: 439-495.

Nr inw. 66, sygn.: Flora Polska H. 14

Franz Herbich: Stirpes rariores Bucovinae, oder die seltener Pflanzen der Bucovina. Stanislawow 1853, gedruckt bei Johann Paul Piller, ss. 68.

Uwaga w starym inwentarzu: „włączono do odbitek: Flora Polska H/9”

Nr inw. 67, stwierdzono brak w $1969 \mathrm{r}$.

Franz Herbich: Additamentum ad floram Galiciae. Przemyśl 1831

Uwaga w starym inwentarzu: „włączono do odbitek: Flora Polska H/10 [lub: H/13]”

Nr inw. 68, sygn.: Polonica 114

Józef Jundziłł: Opisanie roślin w Litwie, na Wołyniu, Podolu i Ukrainie dziko rosnących, iako i oswojonych podług wydania szesnastego układu roślin Linneusza. Wilno 1830, Józef Zawadzki, ss. XII+583.

Oprawa nowa (połowa XX w.), przy niektórych gatunkach ołówkiem znak X, pieczęć na s. tytułowej: I. Czerwiakowski

Nr inw. 69, brak inwentarzowy

K. Linne: Philosophiae botanice. Halae 1809.

Uwaga w starym inwentarzu: „stara opr. wyb. ...”

Nr inw. 70, sygn.: Starodruki

Caroli a Linné: Systema vegetabilium secundum classes ordines genera species cum characteribus et differentiis. Editio decima quinta. Gottingae 1797, ss. XVI+1026+20 nlb.

na s. przedtytułowej wpis Śleńdzińskiego: Ex libris A.J. Śleńdziński, emit Charkoviae 3.(15) Julii 1869.; BO>1

Nr inw. 71, sygn.: I 369

Gustav Lorinser: Botanisches Excursionsbuch für die deutsch-österreichischen Länder und das angrenzende Gebiet. Nach der analytischen Methode bearbeitet von Gustav Lorinser.3. Auflage.Durchgesehen undergänztvon Dr. Friedrich Wilhelm Lorinser. Wien 1871, Verlag von Carl Gerold's Sohn, ss. LXXV+540.

Przy niektórych gatunkach na marginesach napisano ołówkiem liczby, największa 
- 3595 (na s. 512), przy niektórych rodzajach napisano ołówkiem nazwy polskie, np. s. 3 Clematis - Powojnik, s. 5 Hepatica - Trojanek, s. 7 Myosurus - Ukwap ${ }^{28}$, s. 14 Berberis - Kwaśnica, s. 49 Gypsophila - Łyszczyca ${ }^{29}$.

Nr inw. 72, sygn.: II 3500

August Neilreich: Flora von Nieder-Oesterreich. Eine Aufzählung und Beschreibung der im Erzherzogthume Oesterreich unter der Enns wild wachsenden oder in Grossem gebauten Gefässpflanzen, nebst einer pflanzengeografischen Schilderung dieses Landes. Wien 1859, Verlag von Carl Gerold's Sohn, ss. CXXX+1010.

współoprawne: Nachträge zur Flora von Nieder-Oesterreich. Herausgegeben von der k. k. zoologisch-botanischen Gesellschaft in Wien. Wien 1866, Braumüller, ss. VIII+104.

Uwaga w starym inwentarzu: „za oprawę $1 \mathrm{fl}$. 10”.

Nr inw. 73, sygn.: II 3502

August Neilreich: Die Vegetationsverhältnisse von Croatien. Herausgegeben von der $k$. k. zoologisch-botanischen Gesellschaft in Wien. Wien 1868, Braumüller, ss. XLI+288. $\mathrm{BO}>1$

Nr inw. 74, sygn.: II 3503

August Neilreich: Diagnosen der in Ungarn und Slavonien bisher beobachteten Gefässpflanzen, welche in Koch's Synopsis nicht enthalten sind. Wien 1867, Baumüller, Ss. VIII+153.

Uwaga w starym inwentarzu: „za oprawę 75”

Nr inw. 75, brak inwentarzowy

August Neilreich: Nachträge zu Maly's Enumeratio plantarum phanerogamicarum imperii austriaci universi: vorgelegt in der Sitzung vom 3. Juli 1861. Wien 1861, Braumüller, ss. VIII+389.

Uwaga w starym inwentarzu: „za oprawę 75”

Nr inw. 76, sygn.: Słowniki 37

Alexander Pławski: Słownik wyrazów botanicznych. Wilno 1830, J. Zawadzki, ss. VIII+298.

Uwaga w starym inwentarzu: „za oprawę 50 C.”

\footnotetext{
${ }^{28}$ Pomyłka nieznanego autora notatki. Ukwap to Antennaria, natomiast Myosurus - to mysiurek.

${ }^{29}$ Obecnie: gipsówka.
} 
Nr inw. 77, sygn.: Starodruki

Eduard Schmidlin: Anleitung zum Botanisiren und zur Anlegung der Pflanzensammlungen nebst einer leichtfaßlichen Unterweisung im Untersuchen der Pflanzen und einem praktischen Schlüssel zum Auffinden der Gattungen und Arten. Stuttgart 1846, Hoffmann'sche Verlags, Buchhandlung, ss. VI+407.

Uwaga w starym inwentarzu: „za oprawę 50 C.”, oprawa bordowa z poł. XIX w.; pieczęć na s. tytułowej (przyłożona odwrotnie): I. Czerwiakowski; BO>|

Nr inw. 78, sygn.: Polonica

Michał Szubert: Spis roślin ogrodu botanicznego królewskiego Warszawskiego Uniwersytetu. Warszawa 1824, w Drukarni Szkolney, ss. XLIV+583.

Uwaga w starym inwentarzu: „za oprawę 15”; wpis Śleńdzińskiego: Kraków 1/II [18]75 A.J. Śleńdzińskiego; BO>|

Nr inw. 79, stwierdzono brak w 1969 r.

Friedrich L. Thiele: Laub-Moose der Mittelmark. In getrockneten Exemplaren mit vorgedruckten kurzen Beschreibungen nebst Angabe des natürlichen Standorts. Berlin 1832, Trowitsch.

Nr inw. 80, sygn.: II 3528

Jacobo Waga: Flora polska jawnokwiatowych rodzajów czyli botaniczne opisy tak dzikich jako i hodowanych pod otwartym niebem jawnokwiatowych Królestwa Polskiego roślin [...]. Vol I. Warszawa 1847, w drukarni Stanisława Strąbskiego, ss. $\mathrm{XIII+772.}$

Podpis na stronie przedtytułowej: A.J. Śleńdzińskiego, oprawa z poł. XX w. sygn.: II 3529

Jacobo Waga: Flora polska jawnokwiatowych rodzajów czyli botaniczne opisy tak dzikich jako i hodowanych pod otwartym niebem jawnokwiatowych Królestwa Polskiego roślin [...]. Vol II. Warszawa 1848, w drukarni Stanisława Strąbskiego, ss. 827.

Współoprawne: Antoni Waga: Ukaziciel polskich nazwisk na rodzaje królestwa roślinnego, ułożony abecadłowo najprzód od łacińskich do polskich, a powtóre od polskich do łacińskich, dla użytku botaników, ogrodników, rolników, farmaceutów i wszystkich miłośników roślin. ss. XXX+336.

podpis na s. przedtytułowej: A.J. Śleńdziń[skiego], być może podczas oprawy obcięto marginesy, a wraz z nimi i dalszą część podpisu; przy nielicznych gatunkach ołówkiem znak X;

Oprawa nowa z poł. XX w. 
Nr inw. 81, sygn.: Polonica

Alexander Zawadzki: Flora der Stadt Lemberg, oder Beschreibung, der um Lemberg wildwachsenden Pflanzen, nach ihrer Blüthezeit geordnet. Lemberg 1836, Kuhn und Millikowski, ss. nlb. $12+230$.

Uwaga w starym inwentarzu: „za oprawę 40”, oprawa bordowa z poł. XIX w.; BO>| Miały być 2 egzemplarze według starego inwentarza.

Nr inw. 82, sygn.: Polonica

Alexander Zawadzki: Enumeratio plantarum Galiciae \& Bukowinae, oder die in Galizien und der Bukowina wildwachsenden Pflanzen mit genauer Angabe ihrer Standorte. Breslau 1835, Wilhelm Gottlieb Korn, ss. XXIV+200.

Uwaga w starym inwentarzu: „stara oprawa, za wybicie nowej [?] 15”; pieczęć na stronie tytułowej: I. Czerwiakowski; BO>1

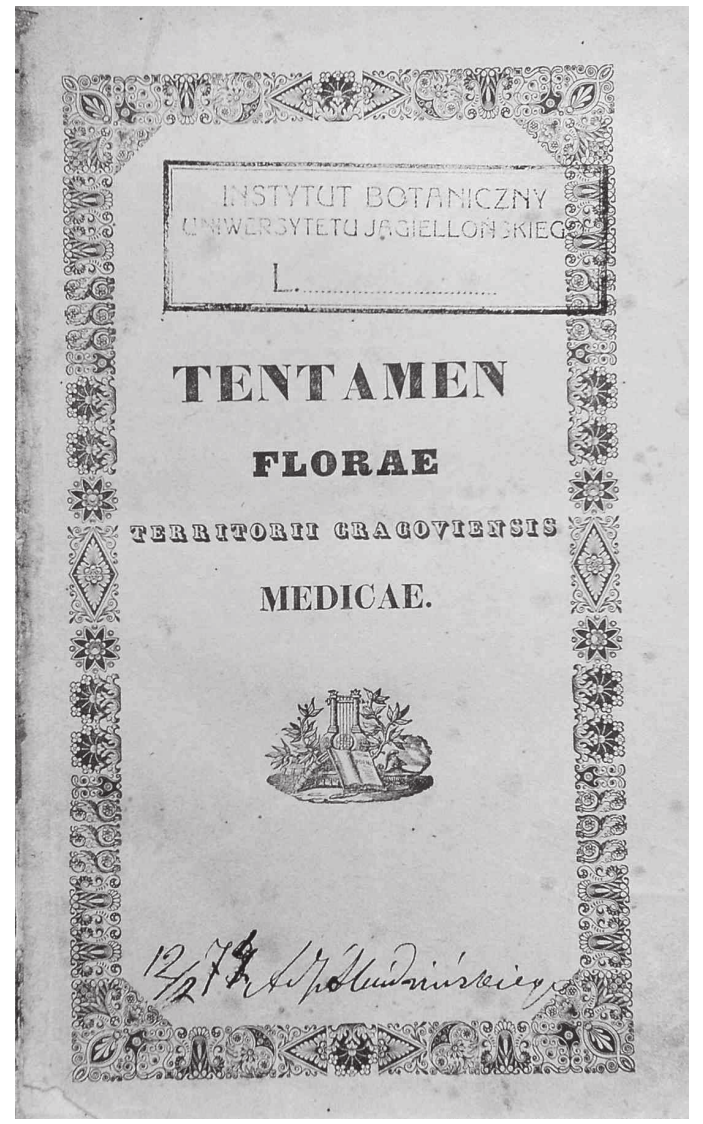

Ryc. 1. S. Dembosz: Tentamen florae territorii cracoviensis... - strona tytułowa z wpisem własnościowym A. J. Śleńdzińskiego. 


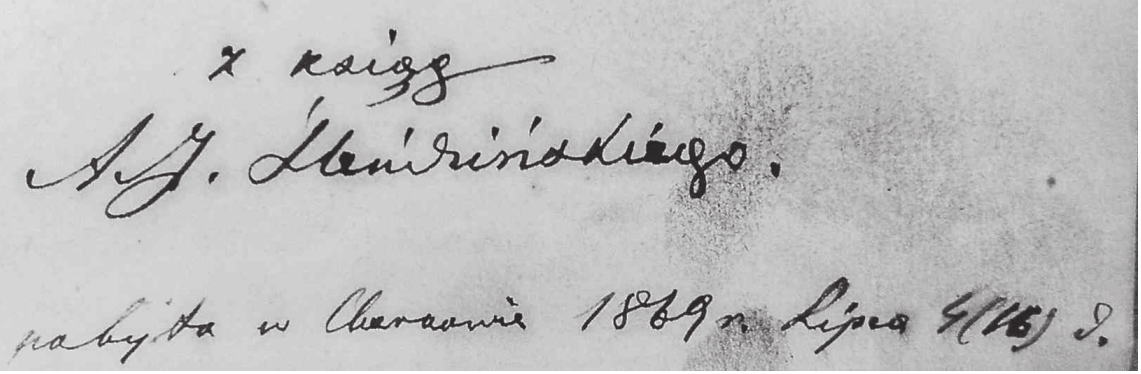

Ryc. 2. J. Loiseleur-Deslongchamps: Considérations sur les céréales et principalement sur les froments - wpis własnościowy A. J. Śleńdzińskiego.

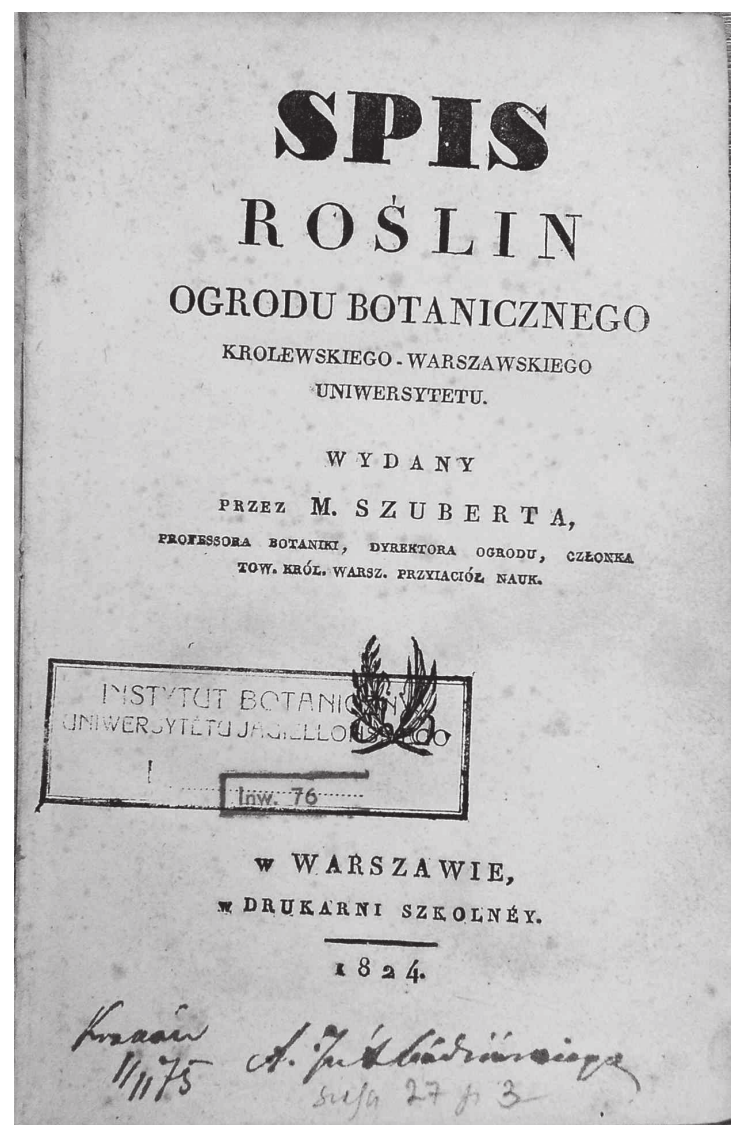

Ryc. 3. M. Szubert: Spis roślin ogrodu botanicznego warszawskiego - strona tytułowa z wpisem własnościowym A. J. Śleńdzińskiego. 


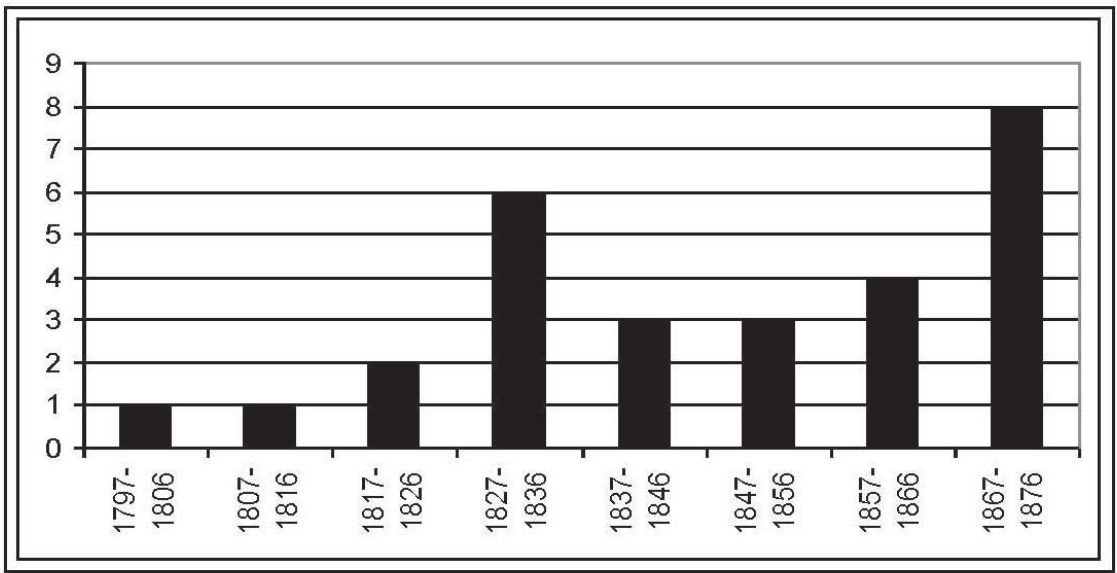

Ryc. 4. Struktura chronologiczna księgozbioru A. J. Śleńdzińskiego

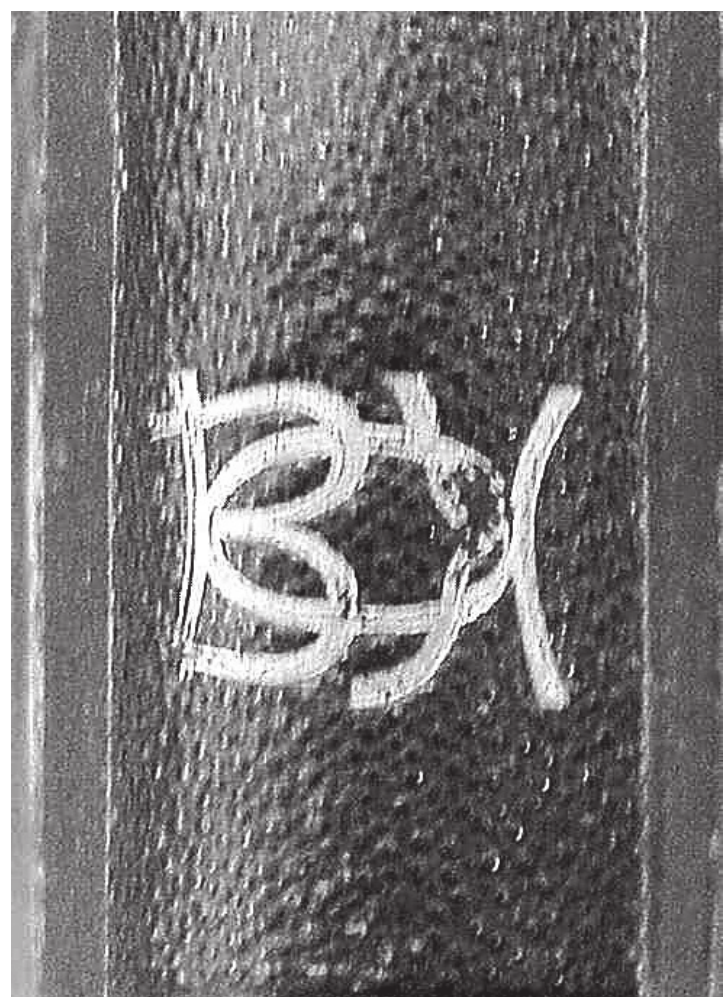

Ryc. 5. Znak imienny introligatora Karola Blechy 